\title{
The Comparative Evaluation of Carbon Mineralization in Soils Contaminated and Uncontaminated with Chromium
}

(Penilaian Bandingan terhadap Mineralisasi Karbon dalam Tanah yang Tercemar dan Tak Tercemar dengan Kromium)

\author{
NACIDE KIZILDAĞ*, HÜSNIYE AKA SAĞLIKER \& CENGIZZ DARICI
}

\begin{abstract}
The environmental risk of Chromium $(\mathrm{Cr})$ pollution is pronounced in soils adjacent to chromate industry. It is important to investigate the functioning of soil microorganisms in ecosystems exposed to long-term contamination by Cr. The aim of this study was to determine the effects of $\mathrm{Cr}$ on carbon mineralization in soil. The study was carried out in soils contaminated and uncontaminated with Cr near and away from a Cr mine in three different districts (Bozluk, Kuzllyüksek and Yanıkçam) of East Mediterranean Region, Turkey. Carbon mineralization were determined in soils humidified $80 \%$ of field capacity at $28^{\circ} \mathrm{C}$ over 30 days under the same laboratory conditions. These results showed that carbon mineralization was greatly inhibited by the presence of $\mathrm{Cr}$ in all contaminated sites. Based on these results, microbial activity can use as an indicator for the Cr pollution level in the soil ecosystems.
\end{abstract}

Keywords: Carbon mineralization; chromium; contamination; soil microorganisms; toxic effect

\section{ABSTRAK}

Risiko alam sekitar bagi pencemaran kromium $(\mathrm{Cr})$ boleh dilihat pada tanah bersebelahan dengan industri kromat. Ia adalah penting untuk mengkaji kefungsian mikroorganisma tanah dalam ekosistem yang sudah terdedah kepada pencemaran jangka lama terhadap Cr. Tujuan kajian ini adalah untuk menentukan kesan Cr pada mineralisasi karbon dalam tanah. Kajian ini dijalankan pada tanah yang tercemar dan tidak tercemar dengan Cr yang berhampiran dan jauh dari lombong Cr di tiga daerah (Bozluk, Kızllyüksek dan Yanıkçam) di kawasan Mediterranean Timur, Turki. Pemineralan karbon ditentukan dalam tanah yang dilembapkan pada $80 \%$ had basah tanih pada suhu $28^{\circ} \mathrm{C}$ selama 30 hari pada keadaan makmal yang sama. Keputusan menunjukkan bahawa mineralisasi karbon sangat terencat dengan kehadiran Cr pada semua kawasan yang tercemar. Berdasarkan hasil ini, aktiviti mikrob boleh digunakan sebagai penunjuk tahap pencemaran $\mathrm{Cr}$ dalam ekosistem tanah.

Kata kunci: Kesan toksik; kromium; mikroorganisma tanah; pemineralan karbon; pencemaran

\section{INTRODUCTION}

The environmental risk of Chromium $(\mathrm{Cr})$ pollution is stated in the regions that are closed to industry of chromate. Activity of soil microorganisms which are came in for Chromium contamination for a long time in ecosystems is significant. Recently, environment pollution of Chromium $(\mathrm{Cr})$, particularly hexavalent $\mathrm{Cr}$, has become a major area of concern (Zayed \& Terry 2003). Due to the fact that the common usage of Chromium in metal industry, it is the most crucial and highly dissolvable metal pollutant around of the world (Mukherjee et al. 2014). It is mostly used in produce of stainless steel and non-iron alloy for covering metals, development of pigments, leather processing and production of catalysts, surface treatments in refractories (Owlad et al. 2010).

$\mathrm{Cr}$ is the element that is 10th largest in number over the mantle of world and obtains in the nature as $\mathrm{Cr}$ (III) or Cr (VI) (Zayed \& Terry 2003). When Cr (VI) is dissolvable and mobile, $\mathrm{Cr}$ (III) exists in soils mainly as stable solids and hardly adsorbed elements (Becquer et al. 2003). Cr exists in unpolluted lands as $\mathrm{Cr}$ (III) due to high scope related to $\mathrm{Cr}$ (VI) - $\mathrm{Cr}$ (III) alteration. Therefore, large amount of $\mathrm{Cr}$ (VI) are mostly limited to polluted areas (James 1996). Many of these areas are highly polluted by $\mathrm{Cr}$ (VI) at concentration more than $1,000 \mathrm{mg} \mathrm{L}^{-1}$ in ground waters (Palmer \& Wittbrodt 1991), but sufficient laboratory researches have not been carried out to address the fate of that high level of $\mathrm{Cr}$ (VI).

Because of the deficiency of proper disposition activities pollution in the land and in the ground waters became critical. The industry of steel alloy plays a major role in $\mathrm{Cr}$ pollution for soil resources (Huang et al. 2009). The accumulation of $\mathrm{Cr}$ in soil may toxic the microorganisms in soil for long term (Viti 2006).

Soil microorganisms are responsible for mineralization of organic matter in soils and nitrogen fixation (Brookes 1995). Heavy metal led to toxic effects for soil biota and they can have a major role over microbial procedures in the soil and decrease the count and activities of soil microorganisms (Obbard 2001). Thereby, ecological balance can change by the presence of these metals (Friedlová 2010; Kot \& Namiesnèik 2000). 
Despite the possible interactions between biotic and chemical components, the reactions of aerobic microbial activities to $\mathrm{Cr}$ have not been examined well (Al- Khashman \& Shawabkeh 2006; Schulin 2007).

The aim of this study was to evaluate the possible effect of $\mathrm{Cr}$ over carbon mineralization in two different soils that are near and away from Aladağ chromium mine under the same conditions during 30 days in laboratory $\left(28^{\circ} \mathrm{C}\right.$ and $80 \%$ of field capacity).

\section{MATERIALS AND METHODS}

Soil samples were taken from two different sites contaminated and uncontaminated by $\mathrm{Cr}$ of Aladağ district of Adana city (mean annual precipitation and temperature; $703 \mathrm{~mm}$ and $13.6^{\circ} \mathrm{C}$ ) in the East Mediterranean region, Turkey. Each of two soil samples was collected from three different sites (Bozluk, Kızılyüksek and Yanıkçam), one from uncontaminated with $\mathrm{Cr}$ away from the mine, the other contaminated with $\mathrm{Cr}$ next to Alada $\mathrm{g} \mathrm{Cr}$ mine.

Soils were collected from the upper $0-20 \mathrm{~cm}$ in October 2013. These samples were sifted by a standard $2 \mathrm{~mm}$ sieve for use in all experiments. The soil texture was determined by the Bouyoucos hydrometer (Bouyoucos 1951), field capacity (\%) by a vacuum pump at $1 / 3$ atmospheric pressure (Demiralay 1993) and $\mathrm{pH}$ with a WTW Inolab $720 \mathrm{pH}$-meter in 1:2.5 soil-water suspension (Jackson 1958). $\mathrm{CaCO}_{3}$ content (\%) was measured with a Scheibler calcimeter (Allison \& Moddie 1965), organic carbon and nitrogen contents (\%) by Anne and Kjeldahl methods, respectively (Duchaufour 1970). For total $\mathrm{Cr}$ contents of soil samples were measured by using ICP-OES spectrophotometer (Liberty, Varian Model).

$\mathrm{K}_{2} \mathrm{Cr}_{2} \mathrm{O}_{7}$ chemical powder (Merck) was used as a $\mathrm{Cr}$ source in the incubation experiments and added to each soil at the equal amount to $50 \%$ of its $\mathrm{Cr}$ content before the $\mathrm{C}$ mineralization measurements. All soil samples with and without to $\mathrm{K}_{2} \mathrm{Cr}_{2} \mathrm{O}_{7}$ were placed in $750 \mathrm{~mL}$ incubation vessels for carbon mineralization. The final moisture contents of soils were adjusted to $80 \%$ of their own field capacity before incubation (Schaefer 1967). $\mathrm{CO}_{2}$ produced from microbial respiration was meausured according to Benlot (1977). The ratio (\%) of carbon mineralization was calculated by dividing the cumulative $\mathrm{C}\left(\mathrm{CO}_{2}\right)$ produced in 30 days to total organic carbon.

The differences between soils contaminated and uncontaminated by $\mathrm{Cr}$ were tested with a variance analysis for carbon and nitrogen mineralization values using a one-way ANOVA. The significance among means was determined by the Tukey HSD test. Three replicates were used for each combined soil for stastistical comparisons. All of the tests were performed at the significance level of $p<0.05$. Statistical analysis were carried out using SPSS v.11.5.

\section{RESULTS}

Some of the physical and chemical properties of soils contaminated and uncontaminated with $\mathrm{Cr}$ were given in Table 1. Total $\mathrm{Cr}$ concentration in soils contaminated with $\mathrm{Cr}$ were high (309.59 ppm) in Yanıkçam whereas uncontaminated soils far away from Bozluk (205.51 ppm) were significantly found low $(p<0.001)$.

All the different three locations of contaminated and uncontaminated soil were classified as sandy clay loam (SCL) textured (Table 1). The field capacities (\%) of same soils were ranged from $21.15 \%$ to $28.35 \%$ and determined higher on uncontaminated soils in general $(p<0.05) . \mathrm{pH}$ values of all of the soils were slightly alkali and no significant differences were observed between them $(p>0.05)$, (Table 1).

The highest carbon content in the contaminated soils of Yanıkçam (2.63\%) and the lowest carbon content in the uncontaminated soils of the same location (1.34\%) were observed and the difference between them is statistically significant $(p<0.001)$. The nitrogen contents of all the soils were ranged from $0.15 \%$ to $0.20 \%$ and higher nitrogen content was determined in contaminated soils. $\mathrm{C} / \mathrm{N}$ ratios of these soil samples were found between 8.74 and 12.92. The carbon mineralization of contaminated and uncontaminated soils taken from 3 different locations (Bozluk, Kızılyüksek and Yanıkçam) near and far from

TABLE 1. Physical and chemical properties all of soil samples

\begin{tabular}{lcccccc}
\hline Sites & \multicolumn{3}{c}{ Contaminated } & Uncontaminated \\
\hline Analyses & Bozluk & Kizılyüksek & Yanıkçam & Bozluk & Kizılyüksek & Yanıkçam \\
\hline Sand $(\%)$ & $61.72 \pm 0.91 \mathrm{bc}$ & $71.36 \pm 0.49 \mathrm{a}$ & $60.54 \pm 0.33 \mathrm{c}$ & $56.57 \pm 1.19 \mathrm{~d}$ & $62.58 \pm 0.95 \mathrm{bc}$ & $65.50 \pm 0.69 \mathrm{~b}$ \\
Silt $(\%)$ & $18.24 \pm 0.62 \mathrm{a}$ & $13.90 \pm 0.26 \mathrm{bc}$ & $15.09 \pm 0.89 \mathrm{abc}$ & $16.40 \pm 0.67 \mathrm{ab}$ & $13.24 \pm 0.74 \mathrm{bc}$ & $11.72 \pm 1.00 \mathrm{c}$ \\
Clay $(\%)$ & $20.71 \pm 0.31 \mathrm{a}$ & $15.84 \pm 0.51 \mathrm{~b}$ & $23.93 \pm 0.88 \mathrm{a}$ & $22.29 \pm 0.50 \mathrm{a}$ & $21.96 \pm 1.23 \mathrm{a}$ & $20.90 \pm 0.22 \mathrm{a}$ \\
\hline Texture type & \multicolumn{7}{c}{ SCL } \\
\hline FC $(\%)$ & $24.40 \pm 1.18 \mathrm{ab}$ & $21.15 \pm 0.92 \mathrm{c}$ & $27.60 \pm 2.25 \mathrm{a}$ & $28.35 \pm 2.10 \mathrm{a}$ & $25.80 \pm 1.25 \mathrm{~b}$ & $24.50 \pm 0.88 \mathrm{ab}$ \\
$\mathrm{pH}$ & $7.38 \pm 0.01 \mathrm{a}$ & $7.45 \pm 0.02 \mathrm{a}$ & $7.41 \pm 0.02 \mathrm{a}$ & $7.38 \pm 0.02 \mathrm{a}$ & $7.39 \pm 0.03 \mathrm{a}$ & $7.40 \pm 0.03 \mathrm{a}$ \\
$\mathrm{C}(\%)$ & $2.10 \pm 0.05 \mathrm{~b}$ & $1.94 \pm 0.10 \mathrm{~b}$ & $2.63 \pm 0.09 \mathrm{a}$ & $1.77 \pm 0.05 \mathrm{~b}$ & $1.95 \pm 0.10 \mathrm{~b}$ & $1.34 \pm 0.04 \mathrm{c}$ \\
$\mathrm{N}(\%)$ & $0.18 \pm 0.00 \mathrm{ab}$ & $0.18 \pm 0.00 \mathrm{ab}$ & $0.20 \pm 0.01 \mathrm{a}$ & $0.16 \pm 0.01 \mathrm{~b}$ & $0.18 \pm 0.01 \mathrm{ab}$ & $0.15 \pm 0.01 \mathrm{~b}$ \\
$\mathrm{C} / \mathrm{N}$ & $11.89 \pm 0.05 \mathrm{ab}$ & $10.62 \pm 0.70 \mathrm{~b}$ & $12.92 \pm 0.31 \mathrm{a}$ & $11.12 \pm 0.28 \mathrm{~b}$ & $10.83 \pm 0.10 \mathrm{~b}$ & $8.74 \pm 0.41 \mathrm{c}$ \\
$\mathrm{Cr}(\mathrm{ppm})$ & $229.17 \pm 0.02 \mathrm{~d}$ & $296.10 \pm 0.01 \mathrm{~b}$ & $309.59 \pm 0.01 \mathrm{a}$ & $205.51 \pm 0.40 \mathrm{~d}$ & $213.43 \pm 0.16 \mathrm{e}$ & $285.07 \pm 0.24 \mathrm{c}$ \\
\hline
\end{tabular}

Different letters denote significant differences $(p \leq 0.05)$ among two sites (contaminated and uncontaminated) and different sites (Bozluk, Kızılyüksek and Yanıkçam) 
Aladağ (Adana) were analysed under controlled conditions $\left(28^{\circ} \mathrm{C}, 30\right.$ days). Moreover, $\mathrm{K}_{2} \mathrm{Cr}_{2} \mathrm{O}_{7}$ was added to the soils at the amounts equal to $50 \%$ of soils own $\mathrm{Cr}$ contents for determining potential effects of $\mathrm{Cr}$ on microorganism activity in these soils. Cumulative carbon mineralization was higher in the uncontaminated soils for each site at the end of the 30 days incubation period $(p<0.05)$. Carbon mineralization of the soils no added $\mathrm{Cr}$ was determined higher compared to the soils that had $\mathrm{Cr}$ supplementary $(p<0.05)$.

At the end of the 30 days incubation period, the maximum cumulative $\mathrm{C}$ mineralization $(15.04 \mathrm{mg}$ $\mathrm{C}\left(\mathrm{CO}_{2}\right) / 100 \mathrm{~g}$ soils $)$ was observed in the uncontaminated soils of Kiz1lyüksek and the minimum value $(9.94 \mathrm{mg}$ $\mathrm{C}\left(\mathrm{CO}_{2}\right) / 100 \mathrm{~g}$ soils $)$ was also determined in the contaminated soils of the same location added $\mathrm{Cr}$ (Figure 1(b)).

Cumulative carbon mineralization value in contaminated and uncontaminated soils of Bozluk was evaluated as 12.93 and $14.34 \mathrm{mg}$, in Cr added contaminated and uncontaminated soils it was valued as 11.76 and 10.23 $\mathrm{mg}$. Microorganism activity of the $\mathrm{Cr}$ added belonging to Bozluk was low $(p<0.05)$, (Figure 1(a)). It was observed that in first six days biodegradable organic substances were used rapidly by microorganisms, between 6 th and 12 th day mineralization velocity moved on slowly and after the 12th day it again gained speed (Figure 1(a)).

When the cumulative carbon mineralization value in contaminated and uncontaminated soils of Kızılyüksek was evaluated as 13.82 and $15.04 \mathrm{mg}$, in $\mathrm{Cr}$ added soils it was valued as 9.94 and $12.16 \mathrm{mg}$, respectively. Either of the soils which were added $\mathrm{Cr}$ or not, the mineralization of the uncontaminated soils was determined higher (Figure 1(b)). When the $\mathrm{C}$ mineralization of each of four soils belonging to Yanıkçam was examined, it was understood that the mineralization was lower in the $\mathrm{Cr}$ added soils (Figure $1(c))$. There was no difference between contaminated and uncontaminated soils of this site $(p<0.05)$. While the maximum $\mathrm{C}$ mineralization value was observed in the uncontaminated soils $(14.16 \mathrm{mg})$, the minimum value was determined in the $\mathrm{Cr}$ added soils $(10.15 \mathrm{mg}$ ).

The carbon mineralization rate was observed the highest in the uncontaminated soils $(0.73 \%)$ and the lowest in the $\mathrm{Cr}$ added soils $(0.56 \%)$ and at a level of $p<0.05$ difference was found between them (Figure 2(a)).

In the soils of Kizilyüksek the highest mineralization rate was observed in the contaminated soil while the lowest rate was observed in the $\mathrm{Cr}$ added soil and between them significant discrepancy was found $(p<0.001)$ (Figure 2(b)). When the carbon mineralization rates in Yanıkçam soils was examined, the maximum mineralization rate in the uncontaminated soils $(0.95 \%)$ and the minimum mineralization rate in the $\mathrm{Cr}$ added soil $(0.39 \%)$ were observed and very significant discrepancy was found between them $(p<0.001)$ (Figure 2(c)).

The decreases between the rates of carbon mineralization of contaminated and uncontaminated soils of 3 locations added $\mathrm{Cr}$ and not, were observed the highest in the contaminated soils of K1zilyüksek (34.29\%) and the lowest value was observed again in the uncontaminated soils same district (12.19\%) (Table 2). The maximum \% decrease was observed in the contaminated soils among all soil samples.
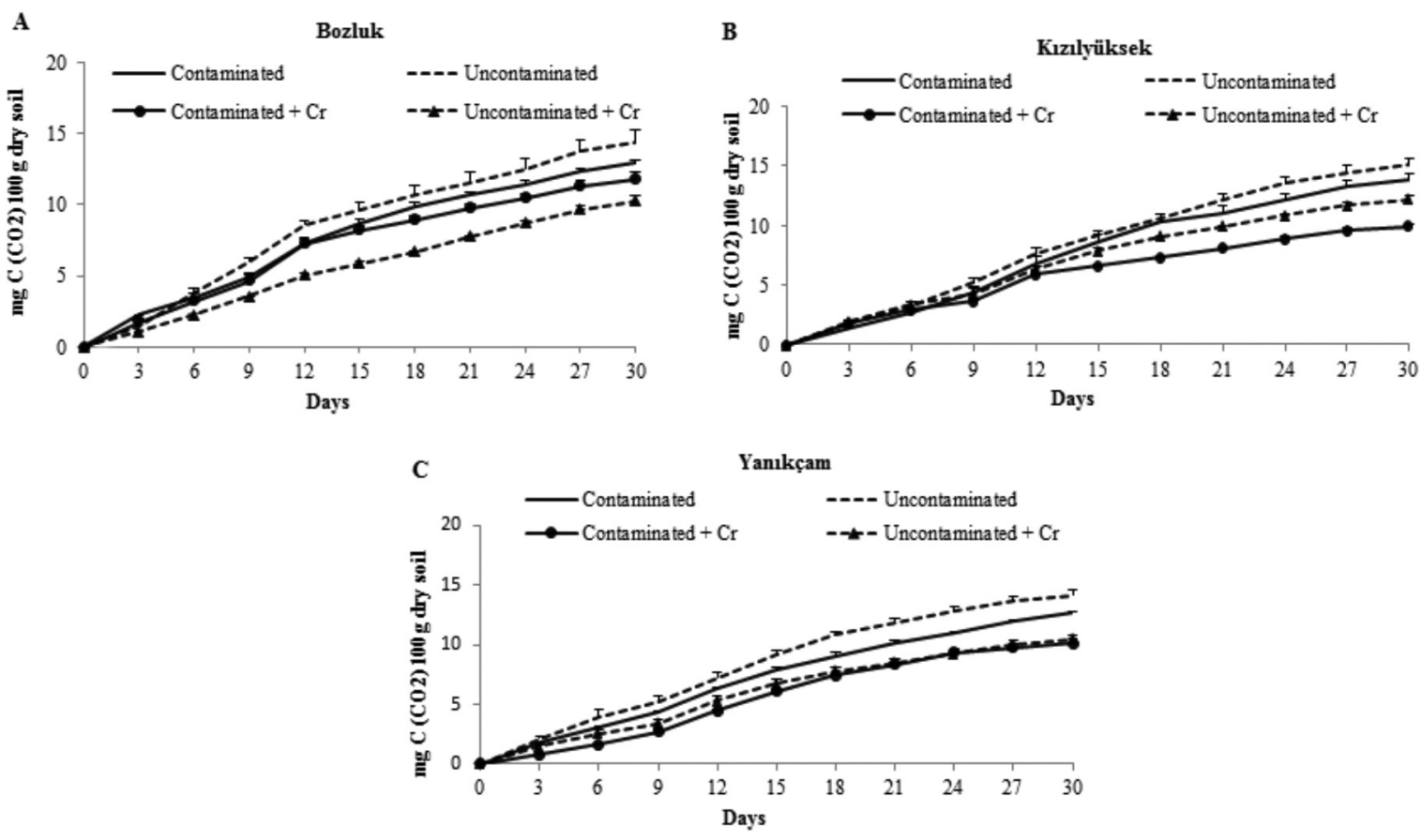

FIGURE 1. Carbon mineralization of contaminated and uncontaminated soils of three different sites (A: Bozluk, B: Kızılyüksek, C: Yanıkçam, $\operatorname{mg~C}\left(\mathrm{CO}_{2}\right) / 100 \mathrm{~g}$ dry soil, $n=3$ ) 

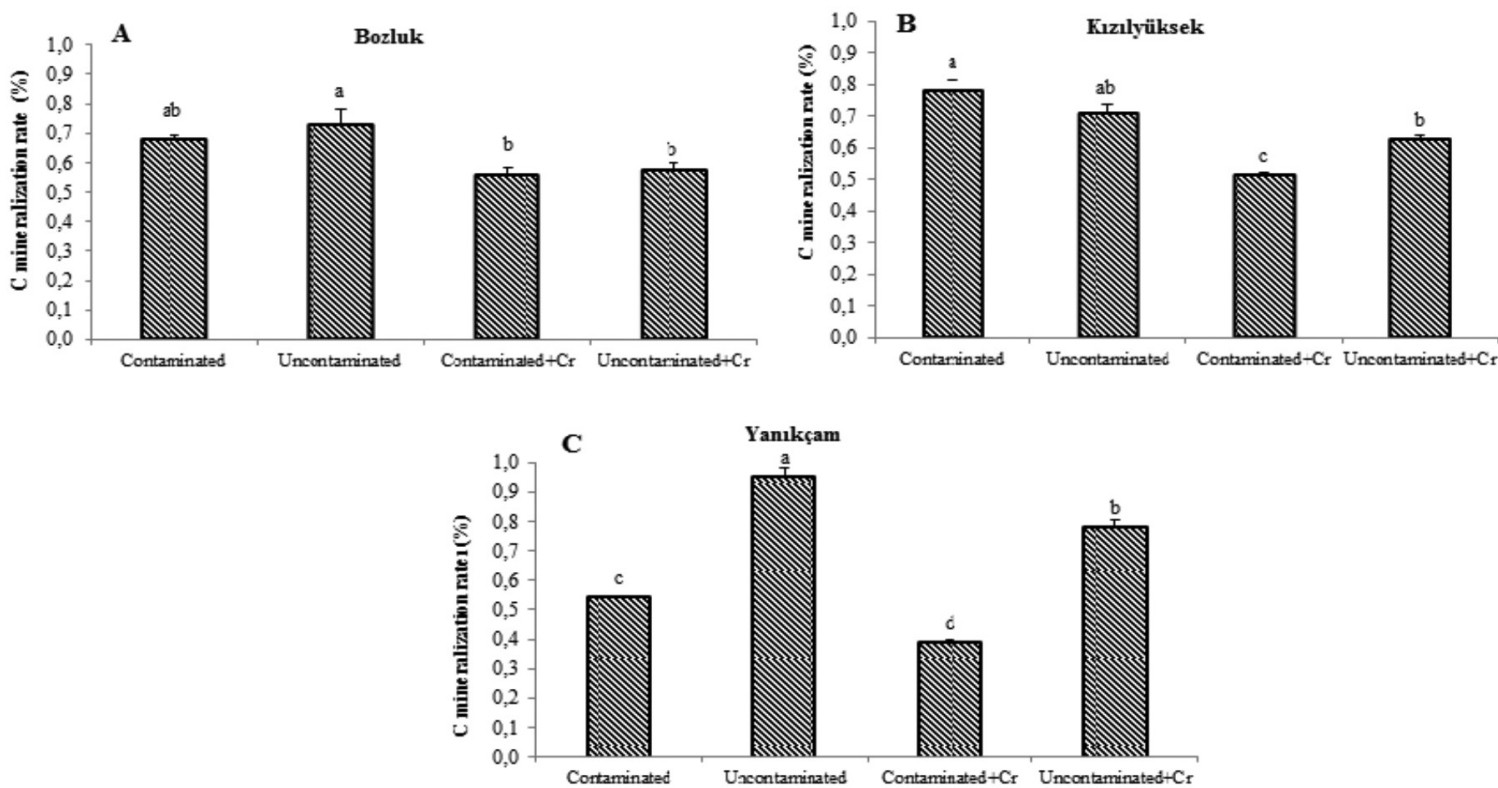

FIGURE 2. The carbon mineralization ratios of contaminated and uncontaminated soils of three different sites (mean $\pm \mathrm{SE} ; n=3$ ). Different letters denote significant differences $(p \leq 0.05)$ among two sites (contaminated and uncontaminated) and different districts [Bozluk (A), Kızılyüksek (B) and Yanıkçam (C)]

TABLE 2. Decreases in the rates of carbon mineralization in the uncontaminated soils in reference to $\mathrm{Cr}$ added soils (\%)

\begin{tabular}{llcccc}
\hline Sites & & $\begin{array}{c}\text { Cr amount } \\
(\mathrm{ppm})\end{array}$ & $\begin{array}{c}\text { Cr no added } \\
\text { C min rate } \\
(\%)\end{array}$ & $\begin{array}{c}\text { Cr added } \\
\text { C min rate } \\
(\%)\end{array}$ & $\begin{array}{c}\text { C min } \\
\text { decrease } \\
(\%)\end{array}$ \\
\hline \multirow{2}{*}{ Bozluk } & Contaminated & 229.17 & 0.68 & 0.56 & 18.01 \\
& Uncontaminated & 205.51 & 0.73 & 0.58 & 20.89 \\
\multirow{3}{*}{ Kizılyüksek } & Contaminated & 296.10 & 0.78 & 0.51 & 34.29 \\
& Uncontaminated & 213.43 & 0.71 & 0.62 & 12.19 \\
& Contaminated & 309.59 & 0.54 & 0.39 & 28.53 \\
& Uncontaminated & 285.07 & 0.95 & 0.78 & 17.70 \\
\hline
\end{tabular}

\section{DISCUSSION}

Except for Yanıkçam location, Cr content of the contaminated soils was higher than the uncontaminated soils. While the highest carbon and nitrogen contents in the contaminated soils were found in Yanıkçam (2.63\% and $0.20 \%$, respectively), in the uncontaminated soils it was found in the Kızilyüksek ( $1.95 \%$ and $0.18 \%$, respectively). Ciarkowska et al. (2016) linked the intense carbon content in the soils that have same fundamental materials to organic substances and some fossil carbon sources in the $\mathrm{Zn}, \mathrm{Pb}, \mathrm{Cd}$ mine region. Nitrogen contents of all the soils in our study were close to each other and ranged from $0.15 \%$ to $0.20 \%$. Frouz et al. (2007) claimed that decomposition of organic substances was slower in the soils with heavy metal. On the other hand, Huot et al. (2013) stated that decomposition of organic substances could be slow depending on the low nitrogen content.
It is known that some physical and chemical properties like $\mathrm{pH}$ of soil and quality and quantity of clay minerals are directly related to heavy metal toxicity (Chibuike \& Obiora 2014; Matos et al. 2001). The pH of soil considerably affects solubility or solvability, utility and toxicity of the metals in the soil (Baath \& Arnebrant 1994). Wang et al. (2007) reported that in the acidic characterization soils even very low metal concentrations affected the soil microorganism in a negative way. The $\mathrm{pH}$ of all of the soil ranged from 7.38 to 7.45 and they had slightly alkali characterization. However, it is possible to mention that inhibiting effect of chromium based on the $\mathrm{pH}$ of these soils.

Microorganism activity is the most sensitive indicator to heavy metal pollution in the soil ecosystems (Boteva et al. 2016; Dai et al. 2004). In the contaminated and uncontaminated soils of three districts, the carbon mineralization decreased in the soils that were added 
$\mathrm{K}_{2} \mathrm{Cr}_{2} \mathrm{O}_{7}$ and $\mathrm{Cr}$ affect the microorganism activity in a negative way. Huang et al. (2009), observed that elevated chromium loadings result in changes in the activity of the soil microorganism, as indicated by the negative correlations between soil microbial population (some bacteria, fungi and actinomycetes being especially sensitive to the presence of some heavy metals like $\mathrm{Cr}$ ) and chromium contents. Moreover, they determined that chromium affected soil microbial population and dehydrogenase enzyme activity negatively in the soils which they took from around the steel alloy factory. Dumestre et al. (1999) emphasized that delay time that was designated from substrate origin mineralization was substantial indicator of the copper pollution. Similar results were also observed in microbial activities in the soils added different heavy metals (Aka \& Darıc1 2004). Also, Nwuche and Ugoji (2008) reported that microbial process of carbon mineralization was inhibited by $\mathrm{Cu}, \mathrm{Zn}$ and $\mathrm{Ni}$. The study results may be related with oxidation or reduction of $\mathrm{Cr}$ compounds in the soil. Bacteria (Megharaj et al. 2003) and plants were negatively affected by $\mathrm{Cr}(\mathrm{VI})$ formed from $\mathrm{Cr}$ (III) added to fresh soil samples (Bartlett \& James 1978).

Based on carbon mineralization rates $(\%)$, in both uncontaminated soils and $\mathrm{K}_{2} \mathrm{Cr}_{2} \mathrm{O}_{7}$ added uncontaminated soils were showed higher mineralization rate compared to contaminated soils. The highest mineralization rate was observed in the uncontaminated soils of Yanıkçam (0.95\%). It was determined that chromium accumulation reduced the rates of mineralization up to $34 \%$ in Kizılyüksek. Marschner and Kalbitz (2003) maintain that impeded soil mineralization is a common property in the presence of heavy metals in the soil. The resistance values are stated by carbon and nitrogen mineralization. Thereby, in dense metal contamination, the percentages of activities similar to these ones are diminished and carbon and nitrogen mineralization increase in the land.

\section{CONCLUSION}

The obtained data in this study manifested that carbon mineralization of the contaminated and uncontaminated soils of three districts decreased in the soils that were added $\mathrm{K}_{2} \mathrm{Cr}_{2} \mathrm{O}_{7}$ and $\mathrm{Cr}$ affect the microorganism activity. According to these findings, it is possible that inhibiting effect of $\mathrm{Cr}$ on these soils. The carbon mineralization in this study was sensitive to site differences and contributed to a better understanding of $\mathrm{Cr}$ effects on activity of microorganism in soils. Heavy metal are known to affect soil microbial populations and their associated activities. In this study, microorganism activity was found as an indicator for the $\mathrm{Cr}$ pollution level in the soil ecosystems.

\section{ACKNOWLEDGEMENTS}

This study was supported by the Research and Application Center of Çukurova University, Turkey (No. FEF2014BAP1).

\section{REFERENCES}

Aka, H. \& Darıc1, C. 2004. Carbon and nitrogen mineralization of lead treated soils in the eastern mediterranean region, Turkey. Soil and Sediment Contamination 13(3): 255-265.

Allison, L.E. \& Moodie, C.D. 1965.Carbonate. In Methods of Soil Analysis Part 2. Chemical and Microbiological Properties. Monogr. 9. 2nd ed., edited by Black, C.A., Evans, D.D., Ensminger, L.E., White, J.L. \& Clark, F.E. Madison (WI): Agronomy Society of America and Soil Science Society of America. pp. 1379-1396.

Al-Khashman, O.A. \& Shawabkeh, R.A. 2006. Metals distribution in soils around the cement factory in southern Jordan. Environmental Pollution 140: 387-394.

Baath, E. \& Arnebrant, K. 1994. Growth rate and response of bacterial communities to $\mathrm{pH}$ in limed and ash treated forest soils. Soil Biology and Biochemistry 26: 995-1001.

Bartlett, R. \& James, B. 1978. Behavior of chromium in soils: III. Oxidation. Journal of Environmental Quality 8: 31-35.

Becquer, T., Quantin, C., Sicot, M. \& Boudot, J.P. 2003. Chromium availability in ultramafic soils from New Caledonia. Science of the Total Environment 301: 251-261.

Benlot, C. 1977. Recherches sur les activites biochimiques dans les successions de sols derives de cendres volcaniques sous climat tropical humide (Zaire- Indonesie). ENS Lab., De Zoologie, Paris. pp. 73-76.

Brookes, P.C. 1995. The use of microbial parameters in monitoring soil pollution by heavy metals. Biology and Fertility of Soils 19: 269-279.

Bouyoucos, G.S. 1951. A recalibration of the hydrometer for making mechanical analysis of soil. Agronomy Journal 43: 434-438.

Boteva, S., Radeva, G., Traykov, I. \& Kenarova, A. 2016. Effects of long-term radionuclide and heavy metal contamination on the activity of microbial communities, inhabiting uranium mining impacted soils. Environmental Science and Pollution Research 23: 5644-5653.

Chibuike, G.U.\& Obiora, S.C. 2014. Heavy metal polluted soils: Effect on plants and bioremediation methods. Applied and Environmental Soil Science 5: 1-12.

Ciarkowska, K., Gargiulo, L. \& Mele, G. 2016. Natural restoration of soils on mine heaps with similar technogenic parent material: A case study of long-term soil evolution in Silesian-Krakow upland Poland. Geoderma 261: 141-150.

Dai, J., Becquer, T., Rouiller, H., Reversat, G., BernhardReversat, F. \& Lavelle, P. 2004. Influence of heavy metals on $\mathrm{C}$ and $\mathrm{N}$ mineralization and microbial biomass in $\mathrm{Zn}$-, $\mathrm{Pb}-, \mathrm{Cu}-$, and Cd-contaminated soils. Applied Soil Ecology 25: 99-109.

Demiralay, İ. 1993. Toprak fiziksel analizleri. Atatürk Üniversitesi Ziraat Fakültesi Yayınları 143: 6-51.

Duchaufour, P. 1970. Precis de Pedologie. Masson et Cie.

Dumestre, A., Sauvé, S., McBride, M.B., Baveye, P. \& Berthelin, J. 1999 Copper speciation and microbial activity in long-term contaminated soils. Archives of Environmental Contamination and Toxicology 36: 124-131.

Friedlová, M. 2010. The influence of heavy metals on soil biological and chemical properties. Soil and Water Research 5: 21-27.

Frouz, J., Elhottová, D., Pižl, V., Tajovský, K., Šourková, M., Picek, T. \& Malý, S. 2007. The effect of litter quality and soil faunal composition on organic matter dynamics in post-mining soil: A laboratory study. Applied Soil Ecology 37: $72-80$. 
Huang, S.H., Peng, B., Yang, Z.H., Chai, L.Y. \& Zhou, L.C. 2009. Chromium accumulation, microorganism population and enzyme activities in soils around chromium-containing slag heap of steel alloy factory. Transactions of Nonferrous Metals Society of China 19: 241-248.

Huot, H., Simonnot, M.O., Marion, P.H., Yvon, J., De Donato, P.H. \& Morel, J.L. 2013. Characteristics and potential pedogenetic processes of a Technosol developing on iron industry deposits. Journal of Soils and Sediments 13: 555568.

Jackson, M.L. 1958. Soil Chemical Analysis. Eaglewood Cliffs: Prentice-Hall, Inc.

James, B.R. 1996. The challenge of remediating chromiumcontaminant soil. Environmental Science and Technology 30: $248-257$

Kot,A.\& Namiesnèik, J. 2000. The role of speciation in analytical chemistry. Trends in Analytical Chemistry 19: 69-79.

Marschner, B. \& Kalbitz, K. 2003. Control of bioavailability and biodegradation of dissolved organic matter in soils. Geoderma 113: 211-235.

Matos, A.T., Fontes, M.P.F., Costa, L.M. \& Martinez, M.A. 2001. Mobility of heavy metals as related to soil chemical and mineralogical characteristics of Brazilian soils. Environmental Pollution 111: 429-435.

Megharaj, M., Avudainayagam, S. \& Naidu, R. 2003. Toxicity of hexavalent chromium and its reduction by bacteria isolated from soil contaminated with tannery waste. Current Microbiology 47: 51-54.

Mukherjee, K., Saha, R., Ghosh, A., Gosh, S.K., Maji, P.K. \& Saha, B. 2014. Surfactant assisted bioremediation of hexavalent chromium by use of an aqueous extract of sugarcane bagasse. Research on Chemical Intermediates 40: $1727-1734$.

Nwuche, C.O. \& Ugoji, E.O. 2008. Effects of heavy metal pollution on the soil microbial activity. International Journal of Environmental Science and Technology 5: 409-414.

Obbard, P. 2001. Ecotoxicological assessment of heavy metals in sewage sludge amended soils. Applied Geochemistry 16: 1405-1411.

Owlad, M., Aroua, M.K. \& Daud, W.M.A.W. 2010. Hexavalent chromium adsorption on impregnated palm shell activated carbon with polyethyleneimine. Biosource Technology 101: 5098-5103.

Palmer, C.D. \& Wittbrodt, P.R. 1991. Processes affecting the remediation of chromium-contaminated sites. Environmental Health Perspectives 92: 25-40.
Schaefer, R. 1967. Caracteres et evolution des activites microbiennes dans une chaine de sols hydromorphes mesotrophiques de la plaine d'alsace première partie: Cadre géographique et milieu édaphique (Doctoral dissertation) (Unpublished).

Schulin, R. 2007. Heavy metal contamination along a soil transect in the vicinity of the iron smelter of Kremikovtzi. Geoderma 140: $52-61$.

Viti, C. 2006. Response of microbial communities to different doses of chromate in soil microcosms. Applied Soil Ecology 34: 125-139.

Wang, J., Lu, Y. \& Shen, G. 2007. Combined effects of cadmium and butachlor on soil enzyme activities and microbial community structure. Environmental Geology 51: 1221-1228.

Zayed, A.M. \& Terry, N. 2003. Chromium in the environment: Factors affecting biological remediation. Plant and Soil 249: 139-156.

\section{Nacide Kızıldağ*}

Central Research Laboratory

Çukurova University

01330, Adana

Turkey

Hüsniye Aka Sağliker

Faculty of Science and Letters

Department of Biology

Osmaniye Korkut Ata University

80000 , Osmaniye

Turkey

Cengiz Darıcı

Faculty of Science and Letters

Department of Biology

Çukurova University

01330, Adana

Turkey

*Corresponding author; email: nkizildag@cu.edu.tr

Received: 10 December 2016

Accepted: 14 March 2017 